\title{
Redistribution of Phosphorus in Soil Through Cover Crop Roots
}

\author{
Júlio C. Franchini, Marcos A. Pavan* and Mário Miyazawa \\ Instituto Agronômico do Paraná - IAPAR; C. P. 481; 86001-970; Londrina - PR - Brazil
}

\begin{abstract}
The objective of this study was to evaluate if cover crops can absorb P from the upper layers and transport it in their roots to subsoil layers. Samples of an Oxisol were placed in PVC columns. Super phosphate fertilizer was applied to the 0-10 cm soil surface layers. The cover crops tested were: Avena strigosa, Avena sativa, Secale cereale, Pisum sativum subsp arvense, Pisum sativum, Vicia villosa, Vicia sativa, Lupinus angustifoliu, Lupinus albus, and Triticum aestivum. After a growth period of 80 days the cover crop shoots were cut off and the soil was divided into $10 \mathrm{~cm}$ layers and the roots of each layer were washed out. The roots and shoots were analyzed separated for total P contribution to the soil. Considerable amount of $P$ was present in the roots of cover crops. Vicia sativa contained more than $60 \%$ of total plant $P$ in the roots. The contribution of Vicia sativa to soil $P$ bellow the fertilized zone was about $7 \mathrm{~kg} \mathrm{ha}^{-1}$. It thus appeared that there existed a possibility of $P$ redistribution into the soil under no tillage by using cover crops in rotation with cash crops. Vicia sativa was the most efficient cover crop species as $P$ carrier into the roots from superficial layer to lower layers.
\end{abstract}

Key words: Phosphorus nutrition, soil phosphorus, green manure, no-tillage

\section{INTRODUTION}

Under no-tillage (NT) P-fertilizer is applied on the soil surface without mechanical incorporation and with time $\mathrm{P}$ tends to accumulate near the soil surface (Muzilli, 1983). Phosphorus is accumulated in the soil because it is not found in a gaseous phase under natural conditions and Pleaching losses are usually minimal due to its strong binding to soil minerals. Thus, $\mathrm{P}$ losses are negligible when compared with those of other chemical elements except where $\mathrm{P}$ is associated with eroded soil particles. It is generally known that the penetration or vertical mobility of the inorganic $\mathrm{P}$ in soil does not occur.

Although a greater mass of roots are found in the upper $10 \mathrm{~cm}$ soil layer in NT system (Henklain et al., 1996), the efficiency of the roots to absorb water and nutrients is uncertain, mainly during a drought period. Therefore, $\mathrm{P}$ redistribution throughout the soil profile will be beneficial to enhance deeper root growth. The distribution of $\mathrm{P}$ may occur as a result of soil profile development and landscape process (Sposito and Reginato, 1992).

Cover crops are widely used in rotation with cash crops in NT with great number of benefits for the soil fertility, plant nutrition, and yields (Calegari et al., 1998; Calegari and Alexander, 1998). They also reported that cover crops used in Brazil present a great diversity in chemical composition, biomass production, and physiological cycle. Noordwijk (1989) and Hairiah and Noordwijk (1989) also reported a great variation in root

\footnotetext{
* Author for correspondence
} 
development of cover crops growing under different environmental condictions. Diest et al. (1973) observed in a radio-isotope experiment that rye-grass increased substantially P-redistribution in the soil profile but the $\mathrm{Ca}$ redistribution downward was limited. These results were associated with high and low mobilities of $\mathrm{P}$ and $\mathrm{Ca}$, respectively, from the aerial parts to the roots.

This work evaluates the efficiency of several cover crops in absorbing $\mathrm{P}$ from the upper layers and transporting $\mathrm{P}$ in their roots to the subsoil.

\section{MATERIAL AND METHODS}

Soil sample was collected from an uncultivated site from the Instituto Agronômico do Paraná (IAPAR) experimental station at Londrina, Brazil. The soil had an original $\mathrm{pH} \mathrm{CaCl}_{2}$ value of 4.1, exchangeable $\mathrm{Ca}, \mathrm{Mg}, \mathrm{K}$, and $\mathrm{Al}$ contents of 3.9, 2.7, 0.8 , and $1.1 \mathrm{cmol} \mathrm{dm}^{-3}$, respectively, total acidity $(\mathrm{H}+\mathrm{Al})$ of $3.0 \mathrm{mmol} \mathrm{dm}{ }^{-3+}, \mathrm{P}$ content of $2.0 \mathrm{mg} \mathrm{kg}^{-1}$, organic carbon content of $0.5 \mathrm{~g} \mathrm{~kg}^{-1}$, and clay, silt, and sand contents of 780, 90 and 130 $\mathrm{g} \mathrm{kg}^{-1}$, respectively.

Dolomitic limestone material $(30 \% \mathrm{Ca}$ and $15 \%$ $\mathrm{Mg}$ ) was mixed with soil in amount equivalent to neutralize $100 \%$ of the total soil acidity $(\mathrm{H}+\mathrm{Al})$. Then, the soil was transferred to a PVC column (length $60 \mathrm{~cm}$ and diameter $15 \mathrm{~cm}$ ) and compacted to a homogeneous bulk density (mean of $1.0 \mathrm{~g} \mathrm{~cm}^{-}$ $\left.{ }^{3}\right)$. Triple superphosphate was mixed in the top 10 $\mathrm{cm}$ soil layer in the amount of $500 \mathrm{mg}$ of $\mathrm{P} \mathrm{kg}^{-1}$ of soil. The columns were brought to field capacity and incubated for 30 days. Then, 10 seeds of each cover crop were sown per column. After germination, 5 seedlings were selected to grow in each column. The following cover crops were used: black oats (Avena strigosa), UFRGS-14 white oats (Avena sativa), rye grass ( $\underline{\text { Secale }}$ cereale), forage pea (Pisum sativum subsp arvense), IAPAR-74 pea (Pisum sativum), hairy vetch (Vicia villosa), common vetch ( $\underline{\text { Vicia }}$

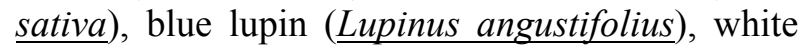
lupin (Lupinus albus), and wheat (Triticum aestivum). After 80 days the shoots of cover crops were harvested and the exposed soil columns were divided into $10 \mathrm{~cm}$ layers and the roots of each layer were washed out. Plant materials were dried at $65^{\circ} \mathrm{C}$ for $48 \mathrm{~h}$ in a forced draft oven, milled to pass $1 \mathrm{~mm}$ sieve and digested in a concentrated $\mathrm{HNO}_{3}$ and $\mathrm{HClO}_{4}$ mixture. Soil $\mathrm{P}$ was extracted by
Mehlich-1 solution $(0.05 \mathrm{M} \mathrm{HCl}+0.0125 \mathrm{M}$ $\mathrm{H}_{2} \mathrm{SO}_{4}$ ). The $\mathrm{P}$ in the plant digest and in the soil double acid solution were determined by inductively coupled plasma (ICP). All treatments had three replicates in a completely randomized block design.

\section{RESULTS AND DISCUSSION}

As expected, the oxisol has a high sorption capacity for $\mathrm{P}$ (Table 1). Only $17 \%$ of the total $\mathrm{P}$ applied were recovered by the Mehlich-1 solution. Lime application increased $\mathrm{pH}, \mathrm{Ca}$, and $\mathrm{Mg}$ to levels for a normal root growth.

Fig. 1 shows the contribution of the cover crop roots to the soil $\mathrm{P}$ in the absence of $\mathrm{P}$ fertilizer. White lupin, IAPAR-74 pea, black oats, and blue lupin were the most efficient sources for soil $\mathrm{P}$ in the entire column $(0$ to $55 \mathrm{~cm})$. IAPAR-74 pea, black oats, and white lupin were the best cover crop for the soil $\mathrm{P}$ bellow the $10-55 \mathrm{~cm}$ layers. The contribution for soil $\mathrm{P}$ for the later case was greater than $0.5 \mathrm{~kg} \mathrm{ha}^{-1}$.

Fig. 2 shows the contribution of the cover crop roots to the soil $\mathrm{P}$ in the presence of $\mathrm{P}$ fertilizer. Common vetch contribution was greater than 15 $\mathrm{kg} \mathrm{ha}^{-1}$ for the soil $\mathrm{P}$ in the entire column. For the layers bellow the $\mathrm{P}$ application zone, common vetch contribution for soil $\mathrm{P}$ was highest than $7 \mathrm{~kg}$ $\mathrm{ha}^{-1}$. Thus it is possible to transfer part of the $\mathrm{P}$ fertilizer from the upper layers to the subsoil through plant roots.

Fig. 3 shows the total $\mathrm{P}$ content in the aerial parts of the cover crops with and without $\mathrm{P}$ fertilizer application. White lupin had the highest capacity of $\mathrm{P}$ accumulation in the aerial parts without $\mathrm{P}$ fertilizer $\left(>9 \mathrm{~kg} \mathrm{ha}^{-1}\right)$. In the presence of $P$ fertilizer, IAPAR-74 pea, black oats, white lupin, hairy vetch, and UFRGS-14 white oats accumulated more than $20 \mathrm{~kg} \mathrm{ha}^{-1}$ of $\mathrm{P}$ on the aerial parts. Although common vetch was the most efficient in $\mathrm{P}$ accumulation in the roots (Fig. 2) it showed the least $\mathrm{P}$ content in the aerial parts (Fig. $3)$. The results of this study indicated that common vetch roots contained about of $65 \%$ of the total $\mathrm{P}$ content of the entire plant. In general, the distribution of $\mathrm{P}$ in the roots with $\mathrm{P}$ fertilizer varied from $65 \%$ (common vetch) to $16 \%$ (IAPAR-74 pea). Thus, depending on the cover crop specie reasonable large quantities of the $\mathrm{P}$ could be carried down into the roots. 
Table 1 - The oxisol has a high sorption capacity for $\mathrm{P}$

\begin{tabular}{c|c|c|c|c|c|c|c|c}
\hline Soil deph & $\mathbf{P}$ & $\mathbf{O . C}$ & $\mathbf{p H C a C l}$ & $\mathbf{A l}$ & $\mathbf{H}+\mathbf{A l}$ & $\mathbf{C a}$ & $\mathbf{M g}$ & $\mathbf{K}$ \\
\hline $\mathbf{c m}$ & $\mathbf{m g k g}^{-1}$ & $\mathbf{g k g}^{-1}$ & \multicolumn{7}{c}{$\mathbf{c m o l}_{\mathbf{c}} \mathbf{k g}^{-1}$} & & & \\
\hline $0-10$ & 94 & 12 & 6.3 & n.d & 3.2 & 4.7 & 2.9 & 0.9 \\
$10-55$ & 2 & 11 & 6.3 & n.d & 2.9 & 3.9 & 2.8 & 1.1 \\
\hline
\end{tabular}

*n.d $=$ not detected

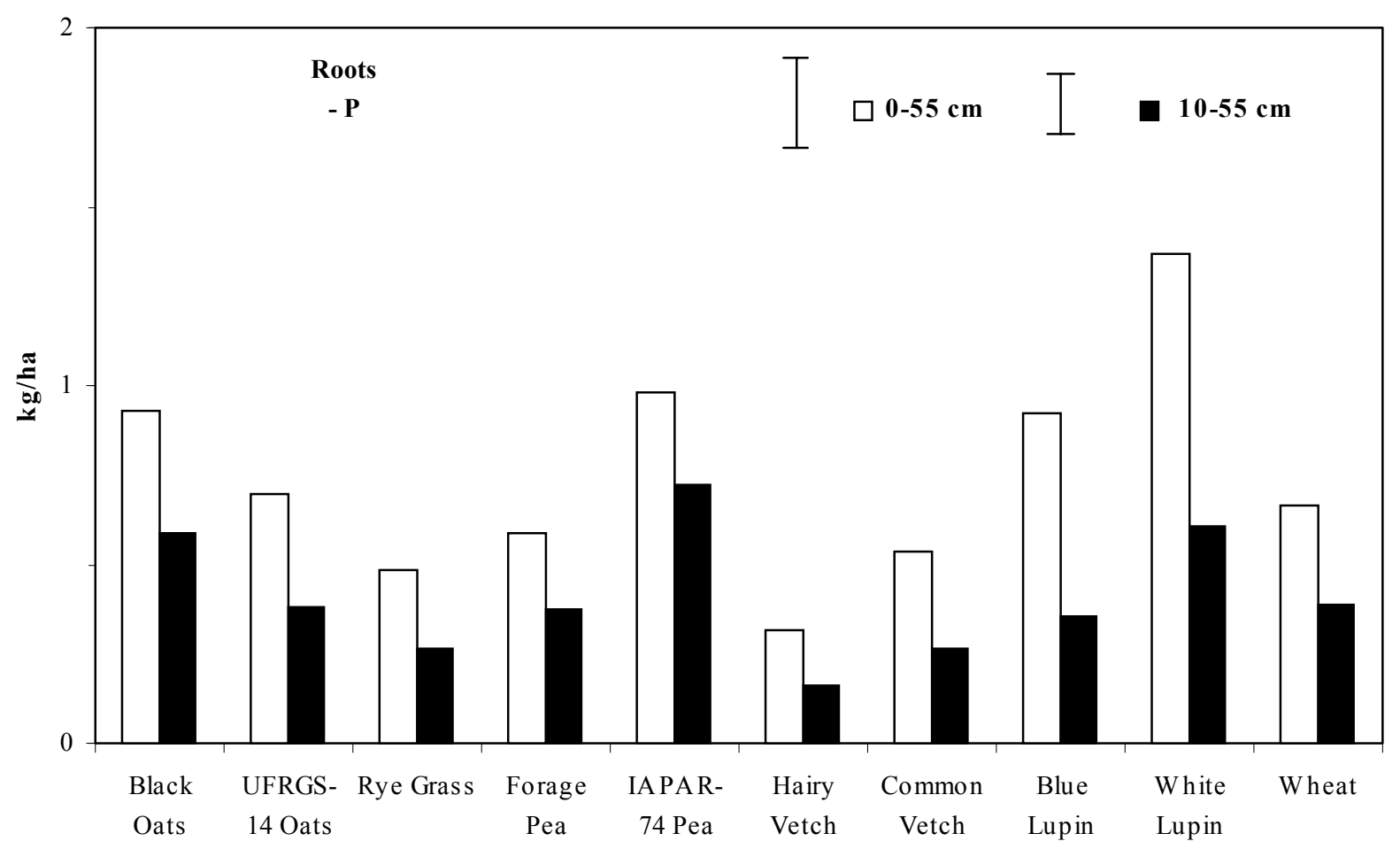

Figure 1 - Phosphorus content in the cover crop root system without P-fertilizer. Vertical bars indicate mean separation by Tukey's test applied at $5 \%$ level of probability.

Fig. 4 shows the total root dry matter content per soil column with and without $P$ fertilizer. Although the black oats and UFRGS-14 white oats had the highest amount of root dry mass, the relative quantities of $\mathrm{P}$ per gram of roots were low. Common vetch presented the highest amount of $\mathrm{P}$ per gram of root dry matter. Thus, the amount of $\mathrm{P}$ transported from the upper layers to the sub soil layers by common vetch was related not only to the root growth but also by increasing in P uptake and root accumulation efficiency.

Schnitzer (1991) pointed out that the highest amount of the total plant $\mathrm{P}$ was present in the soluble organic farm. Thus, it was necessary to mineralize plant $\mathrm{P}$ because the roots absorbed preferentially in the inorganic $\mathrm{P}$ form (Hedley et al., 1982). Therefore, the plant $\mathrm{P}$ becomes available to crops when the organic material is broken down by microorganism. This breaking down process of fresh roots in the subsoil can be a relatively slow action became under NT microbial population and activity decrease with soil depth (Colozzi-Filho et al., 1999). However, the root breaking down in subsoil under NT is possible due to increase rhizosphere microorganism population (Pinton et al., 2000). It is also possible that the cover crops increase $\mathrm{P}$ availability by increasing the solubility of native soil $\mathrm{P}$. These include control of rhizosphere $\mathrm{pH}$, exudation of organic acids and root phosphatases (Randall et al., 2001). 


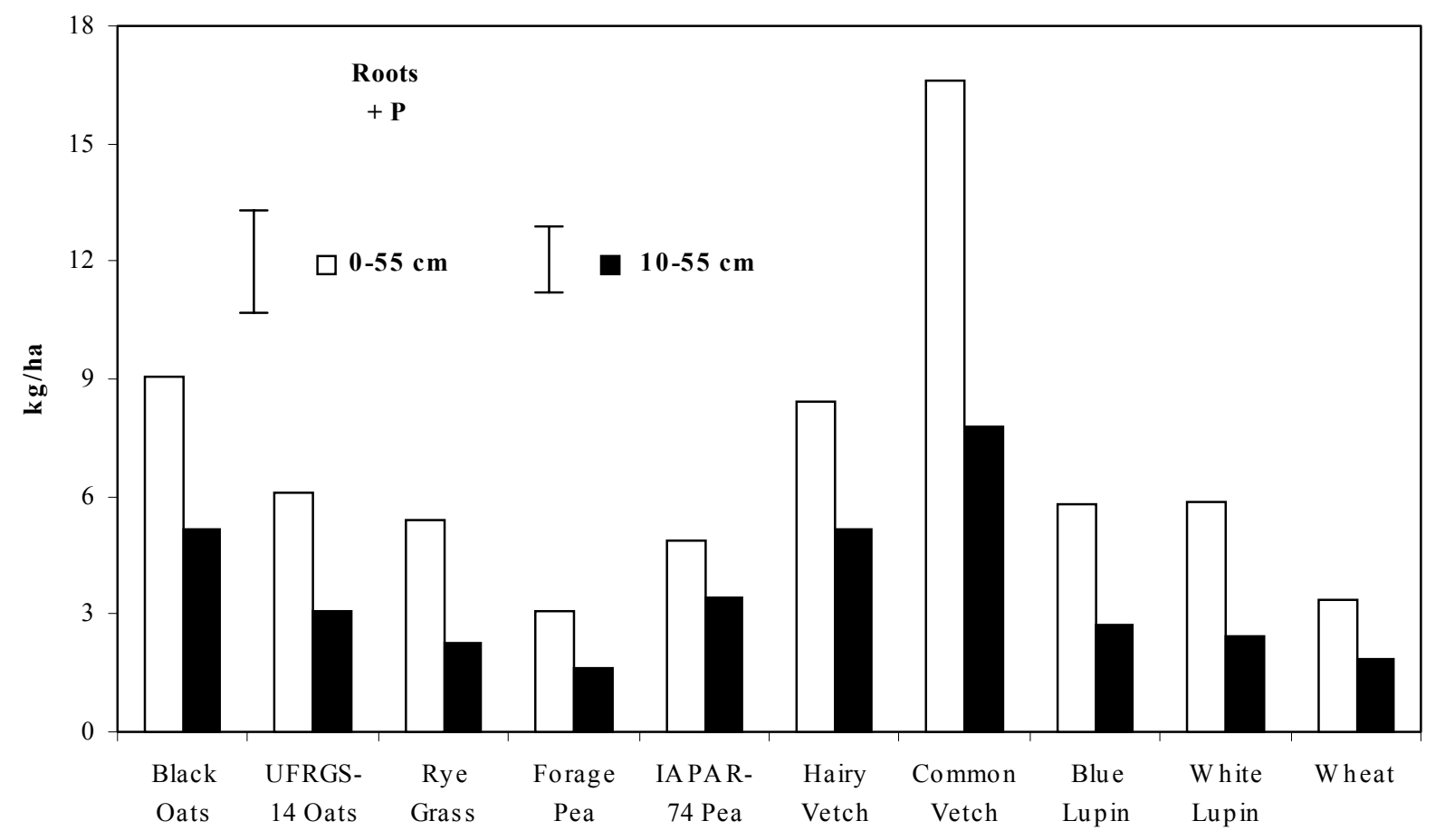

Figure 2 - Phosphorus content in the cover crop root system with P-fertilizer. Vertical bars indicate mean separation by Tukey's test applied at $5 \%$ level of probability.

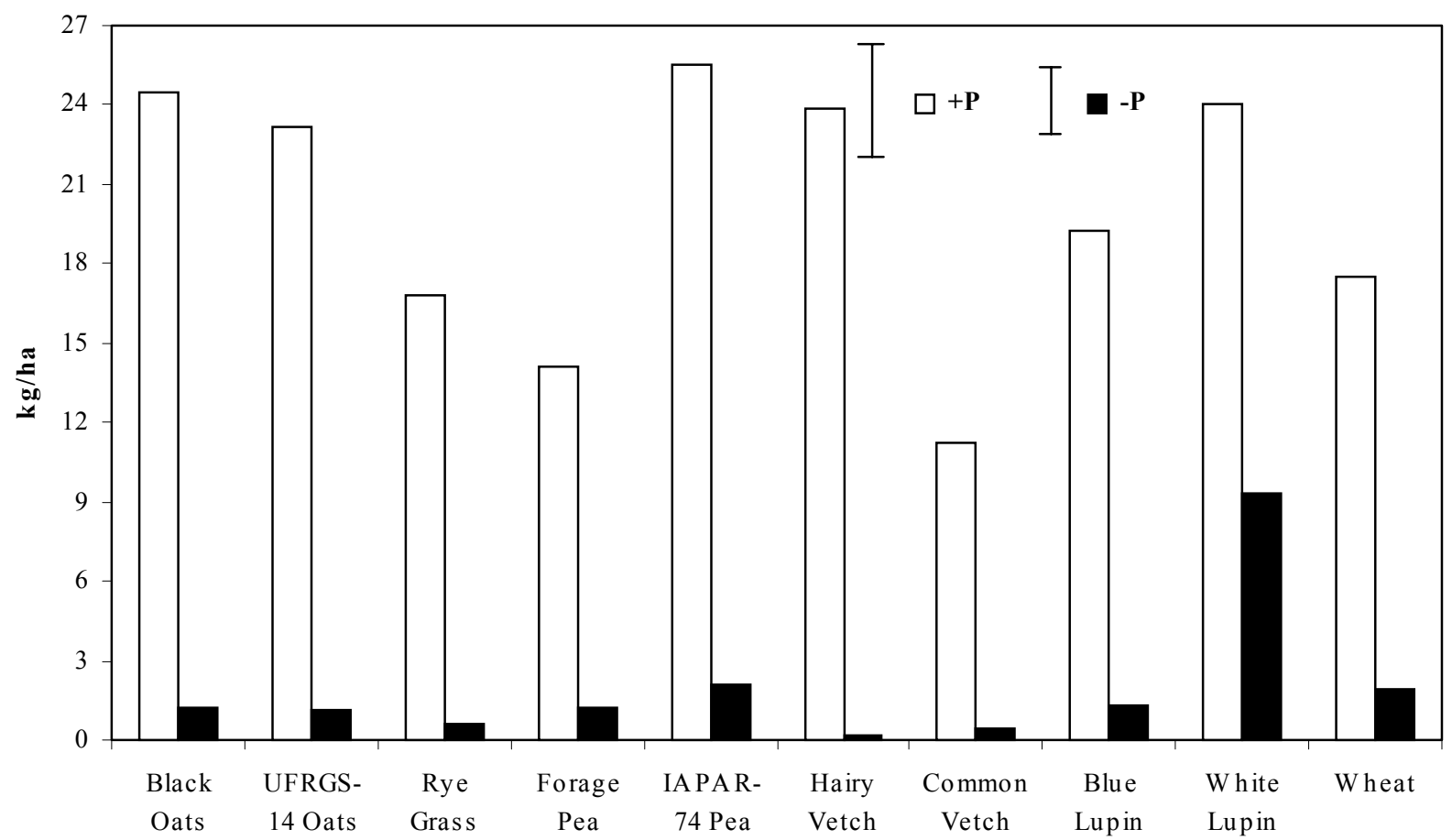

Figure 3 - Phosphorus content in the cover crop shoot parts with and without P-fertilizer. Vertical bars indicate mean separation by Tukey's test applied at $5 \%$ level of probability. 


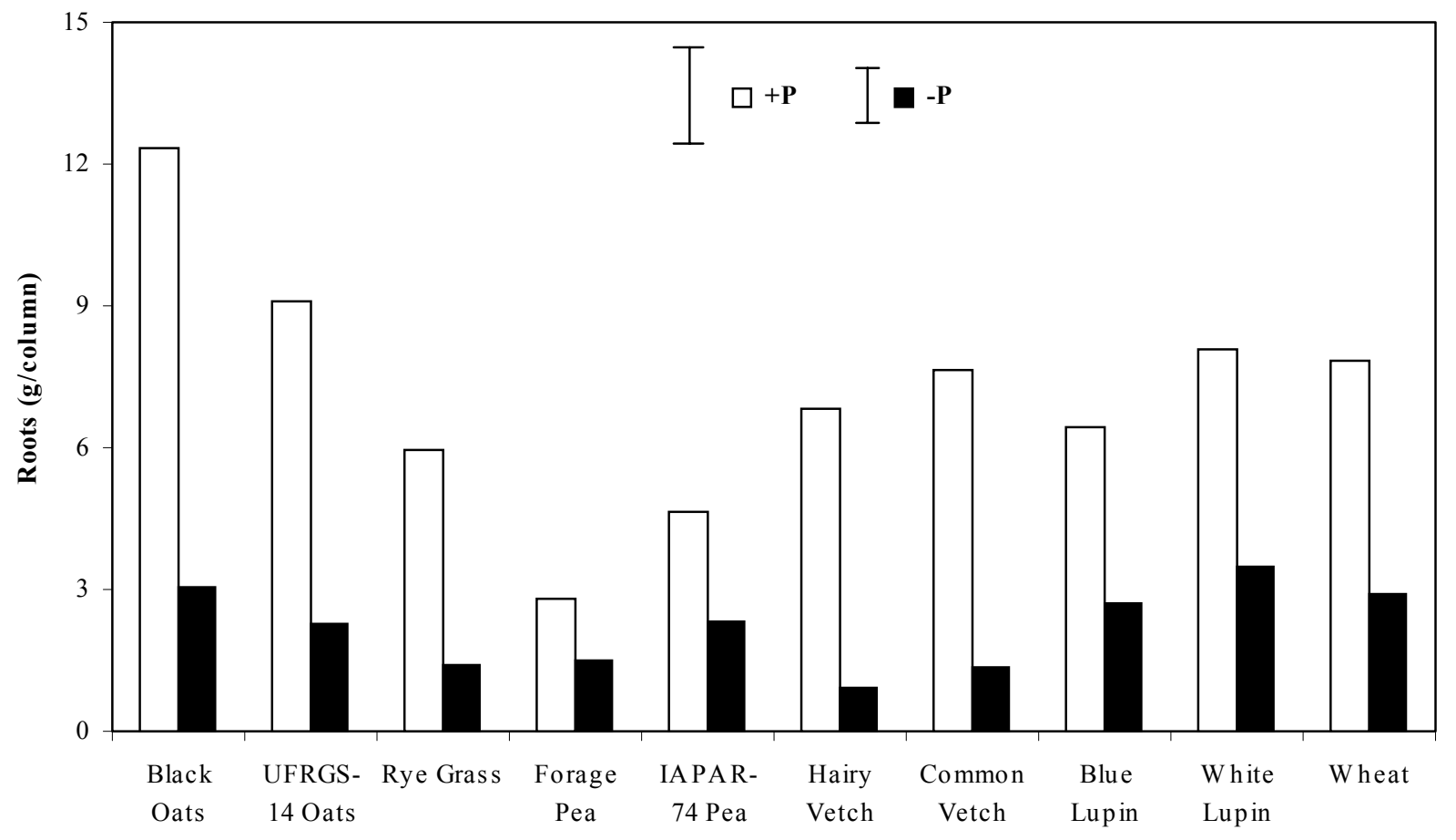

Figure 4 - Root dry matter of the cover crops with and without P-fertilizer. Vertical bars indicate mean separation by Tukey's test applied at $5 \%$ level of probability.

Thus, crop plants can be expected to utilize soil $\mathrm{P}$ more effectively as a result of cover crop management whether the origin of the $\mathrm{P}$ be root cover crop, fertilizer phosphate, or native soil $\mathrm{P}$.

\section{CONCLUSION}

Cover crops were an effective $\mathrm{P}$ transporter down into the roots as illustrative by the increase in root contributions to soil P. Vicia sativa was the most efficiente cover crop specie as P carrier into roots from superficial layer to lower layers.

\section{RESUMO}

Em plantio direto o $\mathrm{P}$ acumula-se próximo da subsuperfície do solo. Devido a importância do P para o desenvolvimento do sistema radicular é benéfico a sua transferência da superfície para a subsuperfície do solo. O objetivo foi avaliar se as plantas de cobertura do solo podem absorver $\mathrm{P}$ na superfície e transferi-la através das raízes para a subsuperfície do solo. Amostras de um latossolo com baixo teor de $\mathrm{P}$ disponível foram transferidas para colunas de PVC. Superfosfato triplo foi aplicado na camada de 0 a $10 \mathrm{~cm}$ de profundidade. Avaliaram-se as seguintes plantas de cobertura: Avena strigosa, Avena sativa, Secale cereale, Pisum sativum subsp arvense, $\underline{\text { Pisum }}$ sativum, Vicia villosa, Vicia sativa, Lupinus angustifoliu, Lupinus albus, e Triticum aestivum. Após 80 dias coletou-se a parte aérea das plantas, dividiu-se o solo em camadas de $10 \mathrm{~cm}$ e separou-se as raízes de cada camada de solo. Analisou-se as raízes e parte aérea e calculou-se a contribuição para o P do solo. As plantas de cobertura acumularam quantidades consideráveis de $\mathrm{P}$ nas raízes e parte aérea. Vicia sativa acumulou cerca de $65 \%$ do total de $\mathrm{P}$ absorvido nas raízes e transferiu com $7 \mathrm{~kg} \mathrm{ha}^{-1}$ de $\mathrm{P}$ para o solo abaixo do local de aplicação do fertilizante fosfatado. Existe a possibilidade da redistribuição de $\mathrm{P}$ no solo, em plantio direto, utilizando-se plantas de cobertura de inverno em rotação com culturas de verão. Vicia sativa foi a mais eficiente na redistribuição do $\mathrm{P}$ da superfície para as camadas subsuperficiais do solo. 


\section{REFERENCES}

Calegari, A. and Alexander, I. (1998), The effects of tillage and cover crops on some chemical properties of an oxisol and summer crop yields in Southwestern Paraná, Brazil. Ad. Geoecos., 31, 1239-1246.

Calegari, A.; Darolt, M. R. and Ferro, M. (1998), Towards sustainable agriculture with no-tillage system. Ad. Geoecos, 31, 1205-1209.

Colozzi-Filho, A.; Balota, E. L. and Andrade, D. S. (1999), Microrganismos e processos biológicos no sistema plantio direto. In: Siqueira, J. D. et al. (ed.). Inter-relação fertilidade, biologia do solo e nutrição de plantas. Lavras : Soc. Bras. Ci. Solo. pp. 487-508.

Deist, J.; Kotzé, A. G. and Jaubert, M. (1973), The role of cover crops in the movement of phosphate and calcium in soils. The Dec. Fruit Grower, 23, 138-141.

Hairiah, K. and Noordwijk, van M. (1989), Root distribution of leguminous cover crops in the humid tropics and effects on a subsequent maize crop. In: van der Heide, J. (ed.). Nutrient management for food Crop production in tropical farming systems. Haren : Inst. Soil Fertility-Univ. Brawijara. pp. 157-169.

Hedley, M. J.; White, R. E. and Nye, P. H. (1982), Plant induced changes in the rhizosphere of rape (Brassica napus, var Emerald) seedlings III. Changes in $\mathrm{L}$ value soil phosphate fraction and phosphate activity. New Phytol., 91, 45-56.

Henklain, J. C.; Guimarâes, M. F.; Vieira, M. J. and Medina, C. C. (1996), Efeito do preparo do solo no desenvolvimento radicular. In: Congresso Brasieliro de Plantio Direto para uma Agricultura Sustentável, 1996 Ponta Grossa. Anais. Ponta Grossa : IAPAR. pp. 103-105.

Muzilli, O. (1983), Influência do sistema de plantio direto, comparado ao convencional, sobre a fertilidade da camada arável do solo. Rev. Bras. Ci. Solo, 7, 95-102

van Noordwijk, M. (1989), Rooting depth in cropping systems in the humid tropics in relation to nutrient use efficiency. In: van der Heide, J. (ed.). Nutrient management for food crop production in tropical farming systems. Haren : Inst. Soil Fertility-Univ. Brawijara. pp. 129-144.

Pinton, R.; Yaranini, Z. and Nannipieri, P. (2000), The rhizosphere biochemistry and organic substances at the soil plant interfase. New York : Marcel Dekker. 440 pp.
Randall, P. J; Hayes, J. E.; Hocking, P. J. and Richardson, A. E. (2001), Root exudates in phosphorus acquisition by plants. In: Ae, N.; Arihara, J.; Okada, K. and Srinivasan, A. (eds.). Plant nutrient acquisition: new perspectives. Tokyo : Springer. pp. 71-100.

Schnitzer, M. (1991), Soil organic matter - the next 75 years. Soil Sci., 151, 41-58.

Sposito, G. and Reginato, R. J. (1992), Opportunities in basic soil science research. Madison : Soil Sci. Soc. Am. pp. 37-40. 